\title{
Assessment of the frailty level of elderly people with chronic kidney disease undergoing hemodialysis
}

Avaliação do nível de fragilidade de idosos com doença renal crônica em tratamento hemodialítico

Fabiana de Souza Orlandi ${ }^{1}$ Keywords Geriatric nursing; Nursing assessment; Frail elderly; Chronic renal failure;

Dialysis

\section{Abstract}

Objective: To assess the frailty level of elderly people with chronic kidney disease undergoing hemodialysis. Methods: This is a cross-sectional study involving 60 participants and carried out at a Renal Replacement Therapy Unit. The Edmonton Frail Scale, translated and validated to Portuguese, was used as the instrument of research.

Descritores

Enfermagem geriátrica; Avaliação Results: Around $35.0 \%$ of the elderly showed no frailty, $26.7 \%$ were vulnerable, $20.0 \%$ showed mild frailty, em enfermagem; Idoso fragilizado; Insuficiência renal crônica; Diálise

Submitted

14 December 2013 $13.3 \%$ moderate frailty and $5.0 \%$ severe frailty.

Conclusion: The frailty level of elderly people with chronic kidney disease undergoing hemodialysis was high and the number of elderly people who are vulnerable to frailty was also high.

Accepted 26 February 2014

\section{Resumo}

Objetivo: Avaliar o nível de fragilidade de idosos renais crônicos em tratamento hemodialítico.

Métodos: Trata-se de um estudo transversal desenvolvido com 60 participantes em uma Unidade de Terapia Renal Substitutiva. Foi utilizada como instrumento de pesquisa a Edmonton Frail Scale, traduzida e validada para a língua portuguesa.

Resultados: Cerca de $35,0 \%$ dos idosos não apresentou fragilidade, 26,7\% estava vulnerável, 20,0\% apresentou fragilidade leve, 13,3\% fragilidade moderada e 5,0\% fragilidade severa.

Conclusão: 0 nível de fragilidade de idosos renais crônicos em tratamento hemodialítico foi elevado assim como foi alto o nível de idosos vulneráveis à fragilidade.

DOI: http://dx.doi.org/10.1590/1982-0194201400007

Corresponding author

Fabiana de Souza Orlandi

Rodovia Washington Luis, km 235,

São Carlos, SP, Brazil.

CEP: 13565-905

fabi_ferreira@yahoo.com.br
${ }^{1}$ Universidade Federal de Sao Carlos, Sao Carlos, SP, Brazil.

Conflicts of interest: there are no conflicts of interest to declare. 


\section{Introduction}

Population aging is a worldwide event. Brazil, which used to be considered a country of young people and had a percentage of elderly people below $6 \%$, has currently around $10.8 \%$ (20.6 million) of people aged 60 or over. The estimate for 2025 is that this percentage will reach $14 \%$ (32 million elderly people). ${ }^{(1)}$

Among the non-transmissible chronic diseases, the chronic kidney disease can be highlighted, to which elderly people are more susceptible due to the changes resulting from aging, such as the reduction in the number of functioning nephrons and decrease in the glomerular filtration. ${ }^{(2)}$

In Brazil, there are 91,314 people undergoing dialysis and $31.5 \%$ of them are aged 65 or over. Among the types of renal replacement therapy, $90.6 \%$ of the patients undergo hemodialysis, as opposed to $9.4 \%$ of patients who undergo peritoneal dialysis. ${ }^{(3)}$

The elderly with terminal chronic kidney disease need to undergo hemodialysis and this is difficult to cope with, since patients experience an abrupt change to their lifestyles, a painful treatment and the thought of death, being important to mention that these factors may contribute to frailty.

Frailty is common among patients with chronic kidney disease undergoing a conventional dialytic treatment. ${ }^{(4)}$

The term frailty in elderly people appeared in 1991 with the following definition: "Frail elderly people are older adults or old people who have a generalized lack of strength and are especially susceptible to diseases or other infections". (5)

Frailty is a clinical syndrome characterized by a reduction in energy levels and resistance to stressful events. However, it is not directly associated with weight loss and can be seen among obese people. ${ }^{(6,7)}$

In an attempt to reach a consensus about the term frailty, there are currently two teams seeking to consolidate its definition. One team is from the United States of America and it proposes a list of measurable criteria to differentiate this physiologic syndrome from clinical entities, comorbidities and incapacities. And the other is from Canada, the $\mathrm{Ca}$ nadian Initiative on Frailty and Aging (CIF-A), that acts together with some European countries, Japan and Israel, where the distinction between frailty, comorbidity and incapacity is also established; however, it disagrees with the American researchers concerning the inclusion of a cognitive function measurement in its criteria. ${ }^{(8)}$

There are instruments in the international literature that propose to measure the frailty of elderly people. Among them, the development and validation of the Edmonton Frail Scale in the University of Alberta, Canada, can be highlighted. The scale was validated to Portuguese and assesses the following nine domains: cognition, general health condition, functional independence, social support, medication use, nutrition, mood, incontinence and functional performance. ${ }^{(9,10)}$

This study was aimed at assessing the frailty level of elderly people with chronic kidney disease undergoing hemodialysis.

\section{Methods}

This is a cross-sectional study that involved 60 participants and took place in a Renal Replacement Therapy Unit located in the state of Sao Paulo, in the Southeast region of Brazil:

The population consisted of people aged 60 or over who had chronic kidney disease and were undergoing hemodialysis.

The subjects were interviewed before the hemodialysis session, using the Edmonton Frail Scale, which assesses nine domains, as follows:

- Cognition: Clock Test for cognitive impairment;

- General Health Condition;

- Functional Independence;

- Social Support;

- Medication Use;

- Nutrition;

- Mood;

- Incontinence;

- Functional Performance: stand up and walk, focused on balance and mobility.

The maximum score that can be reached in the scale is 17 points, which represents the highest frailty level. The scores for analysis of frailty are: 0-4 no 
frailty, 5-6 apparently vulnerable, 7-8 mild frailty, 9-10 moderate frailty and 11 or over, severe frailty.

This scale is a more complete clinical proposal and it is easy to handle and apply in order to detect the frailty of elderly people. ${ }^{(10)}$

The data were entered into an Excel $^{\varpi}$ spreadsheet and a descriptive analysis was performed, being presented through tables and charts with the use of central trend measures (average, median, minimum and maximum) and dispersion measures (standard deviation).

The development of the study complied with the national and international ethical standards concerning researches that involve human beings.

\section{Results}

The 60 subjects studied were characterized by the different genders $(70.0 \%$ were male and $30.0 \%$ female), age between 60 and 89 , with an average of $71.1( \pm 6.9)$ years (Table 1$)$. Among the male elderly, the average age was $70.4( \pm 7)$ years.

Table 1. Sociodemographic characteristics

\begin{tabular}{|c|c|c|c|c|c|}
\hline Variable & $\begin{array}{l}\text { Average } \\
( \pm \mathrm{SD})^{\star}\end{array}$ & Median & $\begin{array}{l}\text { Observed } \\
\text { variation }\end{array}$ & Category & $n(\%)$ \\
\hline Gender & & & & $\begin{array}{l}\text { Male } \\
\text { Female }\end{array}$ & $\begin{array}{l}42(70.0) \\
18(30.0)\end{array}$ \\
\hline $\begin{array}{l}\text { Age } \\
\text { (years) }\end{array}$ & $71.1( \pm 6.8)$ & 70 & $60-89$ & $\begin{array}{l}60-74 \\
75-89\end{array}$ & $\begin{array}{l}46(76.7) \\
14(23.3)\end{array}$ \\
\hline Skin color & & & & $\begin{array}{l}\text { Caucasian } \\
\text { Black } \\
\text { Brown }\end{array}$ & $\begin{array}{c}47(78.3) \\
8(13.3) \\
5(8.4)\end{array}$ \\
\hline $\begin{array}{l}\text { Marital } \\
\text { status }\end{array}$ & & & & $\begin{array}{l}\text { Have a partner } \\
\text { Do not have a partner } \\
\text { Not reported }\end{array}$ & $\begin{array}{c}42(70.0) \\
16(26.6) \\
2(3.4)\end{array}$ \\
\hline $\begin{array}{l}\text { Years of } \\
\text { education }\end{array}$ & & & & $\begin{array}{l}\text { None } \\
1 \text { to } 4 \text { years } \\
5 \text { to } 9 \text { years } \\
10 \text { years or more }\end{array}$ & $\begin{array}{l}14(23.3) \\
22(36.7) \\
11(18.3) \\
13(21.7)\end{array}$ \\
\hline $\begin{array}{l}\text { Income } \\
\text { per } \\
\text { person } \\
\text { (times the } \\
\text { minimum } \\
\text { wage) }^{\star \star}\end{array}$ & $2.8( \pm 2.5)$ & 2 & $1-13$ & $\begin{array}{l}\text { Up to } 1 \\
\text { From } 1.1 \text { to } 5 \\
\text { More than } 5 \\
\text { Not reported }\end{array}$ & $\begin{array}{l}13(21.7) \\
34(56.7) \\
7(11.6) \\
6(10.0)\end{array}$ \\
\hline Religion & & & & $\begin{array}{l}\text { Catholic } \\
\text { Evangelic } \\
\text { Others }\end{array}$ & $\begin{array}{l}45(75.0) \\
9(15.0) \\
6(10.0)\end{array}$ \\
\hline $\begin{array}{l}\text { Housing } \\
\text { situation }\end{array}$ & & & & $\begin{array}{l}\text { Own home } \\
\text { Rent } \\
\text { Others }\end{array}$ & $\begin{array}{c}53(86.7) \\
5(8.3) \\
2(5.0)\end{array}$ \\
\hline
\end{tabular}

* SD - Standard Deviation

As shown in table 1 , there was a predominance of Caucasian people (78.3\%). Most patients were in a serious relationship (70.0\%). In relation to income per person, the average was $2.8( \pm 2.5$; median 2) times the minimum wage (MW) with variation between 1 and 13 times the MW. Concerning education, most participants had completed from 1 to 4 years of study $(36.7 \%)$.

All respondents were religious, 75\% $(n=45)$ were Catholic, 15\% ( $n=9)$ evangelic, and 10.0\% followed other religions. In relation to housing arrangements, $86.7 \%$ owned their homes, $8.3 \%$ were renting and $5 \%$ had other housing arrangements.

It can be observed in table 2 that the main causes of chronic kidney disease were systemic hypertension (51.7\%) and diabetes mellitus type 2 (38.3\%). A small portion had glomerulopathies (3.3\%) and $6.7 \%$ could not inform their condition.

Table 2. Clinical characteristics

\begin{tabular}{lccclcc}
\hline Variable & $\begin{array}{c}\text { Average } \\
( \pm \text { SD) }\end{array}$ & Median & $\begin{array}{c}\text { Observed } \\
\text { variation }\end{array}$ & \multicolumn{1}{c}{ Category } & n(\%) \\
\hline Duration of & 40.7 & 24 & $2.0-295.0$ & Up to 12 & $20(33.3)$ \\
hemodialysis & $( \pm 52.3)$ & & & 12,1 to 60 & $30(50.0)$ \\
(in months) & & & & 60.1 to 300 & $10(16.7)$ \\
Vascular & & & & Arteriovenous fistula & $46(76.7)$ \\
access & & & & Double Lumen Catheter & $14(23.3)$ \\
Underlying & & & & Arterial hypertension & $31(51.7)$ \\
disease & & & & Diabetes Mellitus Type 2 & $23(38.3)$ \\
& & & & Not reported & $4(6.7)$ \\
& & & & Glomerulopathies & $2(3.3)$ \\
Medication & 4.4 & 4 & $1-13$ & 1 to 5 & $41(68.3)$ \\
& & & & 6 to 10 & $13(21.7)$ \\
& & & & Not using/Not reported & $4(6.6)$ \\
& & & & Over 10 & $2(3.4)$ \\
Falls & & & No & $41(68.3)$ \\
& & & Yes & $17(28.3)$ \\
& & & Could not remember / & $2(3.4)$ \\
\hline * & & & Not reported & \\
\hline
\end{tabular}

The average duration of patients' hemodialysis was 40.7 ( \pm 52.3$)$ months, ranging between 2.0 and 295.0 months. Concerning the venous access for hemodialysis, $76.7 \%(n=47)$ had an arteriovenous fistula. As for the use of medication, a significant number of elderly people made use of medication daily $(91.7 \%)$ and $8.3 \%$ did not make use of any drug therapy or were unable to inform. It is important to emphasize that the use of medication ranged from one to 13 drugs per day, with an average of 4.3 (Table 2).

In regards to falls, $68.3 \%$ reported not having had any falls in the previous year, $28.3 \%$ informed they had a fall in the previous year and $3.4 \%$ could not remember or were unable to inform. 
As for the frailty of elderly people with chronic kidney disease undergoing hemodialysis, Table 3 shows that $35 \%(n=21)$ of the subjects being assessed showed no frailty; $26.7 \%(n=16)$ were apparently vulnerable; $20 \%(\mathrm{n}=12)$ showed mild frailty; $13.3 \%(\mathrm{n}=8)$ moderate frailty and $5 \%$ $(\mathrm{n}=3)$ severe frailty.

\section{Discussion}

The restriction of the results of this study is related to the fact that the research design is cross-sectional and does not allow the establishment of the relation between cause and effect.

This research enabled the identification of elderly people with chronic kidney disease who are frail, pre-frail and vulnerable to frailty, allowing new geriatric nursing care interventions to be planned and executed with the population with chronic kidney disease in order to minimize frailty syndrome and stop its evolution, and/or prevent the vulnerable people to become frail.

The predominance of male and Caucasian people in this study is similar to other international and Brazilian researches. Studies have identified the predominance of male and Caucasian people. This shows that male people could be more susceptible to having this disease. ${ }^{(11,12)}$

The average age in this study was $71.1( \pm 6.8)$ years. A study carried out in the same geographic region showed that the average age of the participants was $70.0( \pm 7.5)$ years. $^{(2)}$

Most participants were in a serious relationship (70.0\%). A study undertaken with the purpose of characterizing the population of adult and elderly patients who were undergoing hemodialysis and was developed in four dialysis units located in the city of Ribeirao Preto, in the countryside of Sao Paulo state, have identified that $61.8 \%$ of the respondents were in a serious relationship.

Concerning years of education, most respondents had completed from one to four years of education $(36.7 \%)$ and $23.3 \%$ had not undertaken any education and were illiterate. A study conducted at a Nephrology Unit of a University Hospital iden- tified that $40 \%$ of the respondents had completed from one to four years of education and $6.2 \%$ were illiterate. ${ }^{(13)}$

Taking into account that the average income per person was 2.8 times the minimum wage, the low socioeconomic status reported by the elderly may be related to the type of income received, such as pension payments, since all the respondents were retired. Working is shown to be relevant to people's lives as the professional achievement and as the financial means of supporting the family.

Regarding the variables related to religious conviction, $76 \%$ reported to be Catholic. The relation between religious conviction and health has become a clear paradigm to be established in healthcare; the evidence of the use of these events as support in different disease conditions has become a challenge for science. Religiosity and spirituality play an important part for patients undergoing dialysis and are related to important issues such as quality of life and coping with the disease, and should be taken into consideration by the professionals who provide care to this type of patient. ${ }^{(14,15)}$

In relation to the clinical variables, the results showed that the most predominant underlying disease was the systemic arterial hypertension (51.7\%). In the study about the quality of life of patients with chronic kidney disease undergoing hemodialysis in the same conditions, it was also identified that $55.4 \%$ of the respondents had arterial hypertension as the main cause. ${ }^{(16)}$

The average duration of hemodialysis concerning the participants was $40.7( \pm 52.3)$ months, ranging from two to 295. A study conducted at a Replacement Renal Therapy Unit located in the countryside of Sao Paulo state, with the purpose of characterizing the elderly with chronic kidney disease undergoing hemodialysis and assessing the hope levels through the Herth Hope Scale, identified that it ranged from one and 132 months. ${ }^{(12)}$

Concerning vascular access, $76.7 \%$ had the arteriovenous fistula as venous access, which is believed to be the best way of vascular access to perform hemodialysis in elderly people. However, the chances of occurrences and complications resulting from the access in elderly people are in- 
creased due to the greater vascular frailty, the higher chance of cardiovascular diseases and diabetes and the extensive vascular exploration for previous access. The complications resulting from vascular access lead to an increase in the elderly's morbidity and a rise in costs.

As for medication use, the average number of medications used was 4.4 per day, ranging from a minimum of one medication to a maximum of 13 . In a study involving patients undergoing hemodialysis, the average number of medications was 4.1, ranging from one to 16 . The authors highlighted that the large number of medications may encourage patients not to follow the treatment or to forget to take some medications, resulting in a low adherence. It can be noted, therefore, similar results to those in this research. ${ }^{(13)}$

In relation to falls, $68.3 \%$ of the participants reported not having had any falls in the last twelve months. In another study, when asked if they had suffered any falls in the previous year, $47.5 \%$ of the respondents stated not to have done so. ${ }^{(17)}$

It was found that $38.3 \%$ of the respondents were frail to some degree and $26.7 \%$ were apparently vulnerable.

In the study conducted in the city of Ribeirao Preto, in the countryside of Sao Paulo state, in which the purpose was to verify the inter and intraobserver reproducibility of the Brazilian adapted version of the Edmonton Frail Scale within a group of residing elderly people, the results obtained were that $49.3 \%$ of the subjects showed no frailty, $20.9 \%$ were apparently vulnerable, $16.4 \%$ showed mild frailty, 9\% moderate frailty and $4.5 \%$ severe frailty, totaling $29.9 \%$ respondents with some degree of frailty. It is important to mention that 515 elderly people living in the community participated in the study; however, a subsample of 137 elderly people was selected for psychometric analysis of the scale and a simple randomized sampling was used. ${ }^{(18)}$

In order to explore the predominance of frailty through different instruments and identify the factors associated with frailty in a community living in northern of Taiwan, the results showed that, of the 275 elderly people assessed through the Edmonton
Frail Scale, 60.4\% showed no frailty, $24.4 \%$ were apparently vulnerable and $14.9 \%$ showed different levels of frailty. ${ }^{(19)}$

A study aimed at verifying the frailty levels of elderly people hospitalized in the Medical Center of the Emergency Unit at a University Hospital showed that $4.8 \%$ were apparently vulnerable, $33.3 \%$ showed mild frailty, $19 \%$ moderate frailty and $42.9 \%$ severe frailty. ${ }^{(20)}$

In the study conducted in the city of Embu das Artes, in the state of Sao Paulo, which was aimed at identifying frailty in the elderly, it was shown that $21.4 \%$ were apparently vulnerable and $30.1 \%$ had some degree of frailty, either mild, moderate or severe. ${ }^{(21)}$

There were a high percentage of respondents with some degree of frailty (38.3\%). In addition, it was verified that $26.7 \%$ were vulnerable to the syndrome. Thus, the need for further studies about the frailty of the population with chronic kidney disease in Brazil and worldwide can be highlighted, with the main purpose of developing interventions aimed at minimizing the mentioned syndrome, stopping its evolution and/or preventing frailty to reach the vulnerable population.

\section{Conclusion}

The frailty level of elderly people with chronic kidney disease undergoing hemodialysis was high, and the number of elderly people who were vulnerable to frailty was also high.

\section{Acknowledgements}

This research was supported by the São Paulo Research Foundation (FAPESP), case number 2012/19434-8.

\section{Collaborations}

Orlandi FS contributed to the project design, planning, analysis and interpretation of data, development of the article, critical review of intellectual content and final approval of the version to be published. Gesualdo GD contributed to the implementation of the research, planning, analysis and inter- 
pretation of data, drafting of the article and final approval of the version to be published.

\section{References}

1. Instituto Brasileiro de Geografia e Estatística (IBGE). Censo Demográfico: resultados preliminares [Internet]. Rio de Janeiro, 2011. Disponível em: http://www.ibge.gov.br/home/estatistica/populacao/cens02010/ resultados_preliminares_amostra/notas_resultados_preliminares_ amostra.pdf.

2. Santos AM, Lucena NM, Vale AM. Caracterização Sociodemográfica de idosos com doença renal crônica submetidos a tratamento dialítico em um hospital filantrópico. Rev Bras Ciênc Saúde. 2010;14(4):7-12.

3. Sesso RC, Lopes AA, Thomé FS, Lugon JR, Watanabe Y, Santos DR. Diálise crônica no Brasil - Relatório do censo brasileiro de diálise. J Bras Nefrol. 2012;32(4):380-4.

4. Mansur HN, Damasceno VO, Bastos MG. Prevalência da fragilidade entre os pacientes com doença renal crônica em tratamento conservador e em diálise. J Bras Nefrol. 2012;34(2):153-60.

5. Teixeira IN. Revisão da literatura sobre conceitos e definições de fragilidade em idosos. RBPS. 2008; 21(4):297-305.

6. Mañas LR, Féart C, Mann G, Viña J. Searching for an Operational Definition of Frailty: A Delphi Method Based Consensus Statement. The Frailty Operative Definition-Consensus Conference Project. J Gerontol A Biol Sci Med Sci. 2012; 68(1):62-7.

7. Rockwood K, Mitnitsk A. Frailty defined by deficit accumulation and geriatric medicine defined by frailty. Clin Geriatr Med. 2011;27(1):17-26.

8. Dasgupta M, Rolfson DB, Stolee P, Borrie MJ. Frailty is associated with postoperative complications in older adults with medical problems. Arch Gerontol Geriatr. 2009;48(1):78-83.

9. Fabrício SC, Rodrigues RA. Revisão da literatura sobre fragilidade e sua relação com o envelhecimento. Rev RENE. 2008; 9(2):113-9.

10. Fabrício-Whebe SC, Schiaveto FV, Vendrusculo TR, Haas VL, Dantas RA, Rodrigues RA. Adaptação cultural e validade da Edmonton Frail
Scale - (EFS) em uma amostra de idosos brasileiros. Rev Latinoam Enferm. 2009;17(6):7p.

11. Biavo BM, Martins CT, Cunha LM, Sachs A, Uezima CB, Draibe SA, et al. Aspectos nutricionais e epidemiológicos de pacientes com doença renal crônica submetidos a tratamento hemodialítico no Brasil. J Bras Nefrol. 2012; 34(3): 206-15.

12. Orlandi FS, Pepino BG, Pavarini SC, Santos DA, Mediondo MS. Avaliação do nível de esperança de vida de idosos renais crônicos em hemodiálise. Rev Esc Enferm USP. 2012;46(4):500-5.

13. Sgnaolin V, Figueiredo AE. Adesão ao tratamento farmacológico de pacientes em hemodiálise. J Bras Nefrol. 2012;34(2):109-16.

14. Valcanti CC, Chaves EC, Mesquita AC, Nogueira DA, Carvalho EC. Coping religioso/espiritual em pessoas com doença renal crônica em tratamento hemodialítico. Rev Esc Enferm. 2012;46(4):838-45.

15. Lucchetti G, Almeida LG, Granero AL Espiritualidade no paciente em diálise: o nefrologista deve abordar?. J Bras Nefrol. 2010; 32(1):12832.

16. Ferreira RC, Silva Filho CR. A qualidade de vida dos pacientes renais crônicos em hemodiálise da região de Marília, São Paulo. J Bras Nefrol. 2011;33(2):129-35.

17. Avelar JK, Pires FC, Cortes VF. Influência dos níveis de paratormônio em quedas entre idosos e adultos em hemodiálise. Rev Enferm UFSM. 2012;2(1):125-34.

18. Fabricio-Whebe SC, Cruz IR, Haas VJ, Diniz MA, Dantas RA, Rodrigues RA. Reprodutibilidade da versão brasileira adaptada da Edmonton Frail Scale para idosos residentes da comunidade. Rev Latinoam Enferm. 2013;21(6):1336.

19. Chang $\mathrm{Cl}$, Chan DC, Kuo KN, Hsiung CA, Chen CY. Prevalence and correlates of geriatric frailty in a northen Taiwan community. J Formos Med Assoc. 2011;110(4):247-57.

20. Storti LB, Fabricio-Whebe SC, Kusumota L, Rodrigues RA, Marques S. Fragilidade de idosos internados na clínica médica da unidade de emergência de um hospital geral terciário. Texto \& Contexto Enferm. 2013;22(2):452-9.

21. Fernandes HC, Gaspar JC, Yamashita CH, Amendola F, Alvarenga MR, Oliveira MA. Avaliação da fragilidade de idosos atendidos em uma unidade da estratégia saúde da família. Texto \& Contexto Enferm. 2013;22(2):423-33. 